\title{
Cytogenetic analyses of two Curimatidae species (Pisces; Characiformes) from the Paranapanema and Tietê Rivers
}

\author{
De Rosa, LVS ${ }^{\mathrm{a}}$, Foresti, F. ${ }^{\mathrm{a}}$, Martins, C. ${ }^{\mathrm{a}}$, Oliveira, C. ${ }^{\mathrm{a}}$, Sobrinho, PE. ${ }^{\mathrm{a}}$ and Wasko, AP. ${ }^{\mathrm{b} *}$ \\ ${ }^{a}$ Departamento de Morfologia, Instituto de Biociências, \\ Universidade Estadual Paulista - UNESP, CEP 18618-000, Botucatu, SP, Brazil

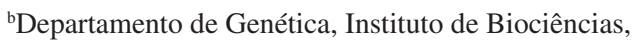 \\ Universidade Estadual Paulista - UNESP, CEP 18618-000, Botucatu, SP, Brazil \\ *e-mail: awasko@ibb.unesp.br \\ Received May 6, 2005 - Accepted July 18, 2005 - Distributed May 31, 2007
}

(With 3 figures)

\begin{abstract}
Cytogenetic analyses were performed in two Curimatidae species (Steindachnerina insculpta and Cyphocharax modesta) from the Paranapanema and Tietê Rivers (São Paulo State, Brazil), showing a karyotype composed of 54 meta-submetacentric chromosomes in both species. Silver- and chromomycyn-staining and fluorescent in situ hybridization (FISH) using a 18S rDNA probe indicated that the nucleolar organizer regions (NORs) of both species are localized in the terminal region of the long arm of two metacentric chromosomes. Although a single NOR system was evidenced in both analyzed species, S. insculpta and C. modesta presented the nucleolar organizer regions in distinct chromosome pairs, indicating that these cistrons can be considered cytogenetic markers. Variation on the amount and distribution of the constitutive heterochromatin (C-bands) could also be detected between the two species - while S. insculpta presented few heterochromatic blocks, intensely stained C-bands were evidenced in C. modesta specially in the terminal region of the long arm of the NOR-bearing chromosomes. Although most Curimatidae species have been characterized by homogeneous karyotypes, isolated populations could be established under different environmental conditions leading to karyotype micro-structure variations specially related to the NORs localization and C-banding distribution. The obtained data were useful for the cytogenetic characterization and differentiation of S. insculpta and C. modesta and could be used in evolutionary inferences in the Curimatidae group.
\end{abstract}

Keywords: constitutive heterochromatin, Cyphocharax modestus, fish, NOR, Steindachnerina insculpta.

\section{Análises citogenéticas de duas espécies de Curimatidae (Pisces; Characiformes) dos rios Paranapanema e Tietê}

\begin{abstract}
Resumo
Análises citogenéticas foram realizadas em duas espécies de Curimatidae (Steindachnerina insculpta e Cyphocharax modestus) provenientes dos rios Paranapanema e Tietê (Estado de São Paulo, Brasil), evidenciando um cariótipo composto por 54 cromossomos meta-submetacêntricos em ambas as espécies. Coloração com nitrato de prata e cromomicina e hibridação in situ fluorescente (FISH), utilizando uma sonda de DNAr 18S, mostraram que as regiões organizadoras de nucléolos (RONs) de ambas as espécies estão localizadas na região terminal do braço longo de dois cromossomos metacêntricos. Embora as espécies analisadas tenham apresentado um sistema de RONs simples, S. insculpta e C. modesta apresentaram as regiões organizadoras de nucléolos em distintos pares de cromossomos, indicando que estes cístrons podem ser considerados marcadores citogenéticos. Variação na quantidade e distribuição de heterocromatina constitutiva (bandas C) também pôde ser detectada entre as duas espécies - enquanto S. insculpta apresentou poucos blocos heterocromáticos, bandas $\mathrm{C}$ intensamente coradas foram evidenciadas em $C$. modesta especialmente na região terminal do braço longo dos cromossomos portadores de RONs. Embora a maioria das espécies de Curimatidae seja caracterizada por cariótipos homogêneos, populações isoladas podem ter se estabelecido sob condições ambientais distintas, levando à ocorrência de variações na micro-estrutura cariotípica especialmente relacionadas à localização das RONs e à distribuição das bandas $\mathrm{C}$. Os dados obtidos mostraram-se úteis para caracterização e diferenciação citogenética de $S$. insculpta e C. modesta e podem ser utilizados em inferências evolutivas no grupo Curimatidae.
\end{abstract}

Palavras-chave: heterocromatina constitutiva, Cyphocharax modestus, peixes, RON, Steindachnerina insculpta. 


\section{Introduction}

Neotropical fish fauna can be characterized either by the occurrence of stable karyotypic groups as well as by divergent ones with an extensive chromosome diversity (e.g. Oliveira et al., 1988; Galetti, 1998). In the order Characiformes, these two main general trends of chromosome evolution have been found. Thus, while several taxa show a chromosome evolution relatively divergent concerning to the karyotype macrostructure, other fish groups share a common karyotype structure and equal number of chromosomes (Bertollo et al., 1986; Oliveira et al., 1988; Arefjev, 1990; Galetti et al., 1994).

The family Curimatidae is composed of eight genera and approximately 120 species distributed throughout South and Central America (Weitzman and Vari, 1998) where they are commonly known as "saguirus" or "papa-terras", and represent a fish group found in several freshwater ecosystems including rivers, streams, and lakes (Vari, 1987). Previous cytogenetic data showed a macro-structural karyotype stability of Curimatidae since most studied species present a diploid number of 54 metacentric and submetacentric chromosomes (Scheel, 1973; Galetti et al., 1981; Pauls and Bertollo, 1990; Cestari et al., 1990; Galetti et al., 1991; Feldberg et al., 1992; Galetti et al., 1994; Navarrete and Julio, 1997), supporting a hypothesis of monophyly for the group. The conservation of a basic karyotype formulae composed of 54 biarmed chromosomes is also observed in Prochilodontidae, Anostomidae, and Chilodontidae (Brum and Galetti, 1997). These fish groups and Curimatidae also share osteological and anatomical characters, comprising a monophyletic unit (Vari, 1983, 1989; Vari et al., 1995).

Despite the great karyotype similarity observed among the Curimatidae so far studied, karyotype divergences can also be found in some species, such as Potamorhina altamazonica $(2 \mathrm{n}=102)$, P. latior $(2 \mathrm{n}=56)$, Curimata ocellata $(2 \mathrm{n}=56)$ (Feldberg, 1990), Cyphocharax sp. $(2 \mathrm{n}=58)$ (Venere, 1991), C. platanus $(2 \mathrm{n}=58)$ and Potamorhina squamoralevis $(2 \mathrm{n}=102)$ (Brassesco et al., 2004), and seem to be related to fission events (Scheel, 1973; Venere, 1991; Feldberg et al., 1987, 1992,1993; Navarrete, 1996). Microstructural changes in chromosome formula, as well as in the C-bands and nucleolar organizer regions (NORs) distribution, have also been described in this fish group (Venere and Galetti, 1989).

Cytogenetic studies can still be considered scarce in Curimatidae, due to its high genera and species diversity. In order to improve cytogenetic data on this group, the karyotype structure of Steindachnerina insculpta and Cyphocharax modestus from two Brazilian river basins was analyzed by Giemsa-, silver nitrate-, and chomomycyn-staining, 18S rDNA fluorescent in situ hybridization, and $\mathrm{C}$-banding.

\section{Material and Methods}

\subsection{Sample collection}

Analyses were performed in the Curimatidae species Steindachnerina insculpta and Cyphocharax modesta, both from the Paranapanema River (Jurumirim Hydroeletric Reservoir, border municipality of Paranapanema and Angatuba, São Paulo State, Brazil) and the Tietê River (municipality of Botucatu, São Paulo State, Brazil). 23 individuals of S. insculpta were collected in the Paranapanema River (5 males and 1 female) and in the Tietê River ( 5 males and 12 females). A total of 27 specimens (18 males and 9 females) and 12 specimens (3 males and 9 females) of $C$. modesta were caught in the Paranapanema River and Tietê River, respectively. The analyzed animals were deposited in the museum of the Laboratório de Biologia e Genética de Peixes, Instituto de Biociências, UNESP-Botucatu, Brazil.

\subsection{Chromosome analysis}

Mitotic chromosomes were obtained from kidney cell suspensions based on the method described by Foresti et al. (1993). Analysis of the constitutive heterochromatin (C-banding) was performed as described by Sumner (1972), with some minor modifications. The nucleolar organizer regions (NORs) were identified by silver nitrate (Howell and Black, 1980) and chromomycyn (CMA $)$ staining (Schweizer, 1976), and also by florescent in situ hybridization (FISH) (Pinkel et al., 1986; Hamkalo and Elgin, 1991; Martins and Galetti, 1999; Wasko and Galetti, 2000). FISH experiments were performed using a PCR-generated 18S rDNA of Oreochromis niloticus (kindly provided by Claudio Oliveira) as a probe labeled by nick translation with biotin-dATP (Bionick $^{\mathrm{TM}}$ Labeling System-Gibco. BRL).

\section{Results}

All analyzed individuals of Steindachnerina insculpta and Cyphocharax modestus, from the Paranapanema and Tietê Rivers, evidenced a standard karyotype with a diploid number of $2 n=54$, consisting exclusively of metacentric and submetacentric chromosomes (Figures 1 and 2). Small supernumerary chromosomes were identified in some individuals of $C$. modesta from the Paranapanema River (Santos et al., in press). No significant differences were observed between the karyotypes of $S$. insculpta and $C$. modesta, as well as between the samples of each species from the Paranapanema and Tietê Rivers. In addition, no chromosome differences were found among males and females of either species.

Silver staining evidenced that the Ag-nucleolar organizer regions (NORs) are localized at the terminal region of the long arm of two large metacentric chromosomes in S. insculpta (Figure 1) and C. modestus (Figure 2). However, a species-specific NOR location was evidenced - while NORs were seen on the chromosome pair 7 in $S$. insculpta, they were visualized on the chromosome pair 2 in C. modesta (Figures 1 and 2; 


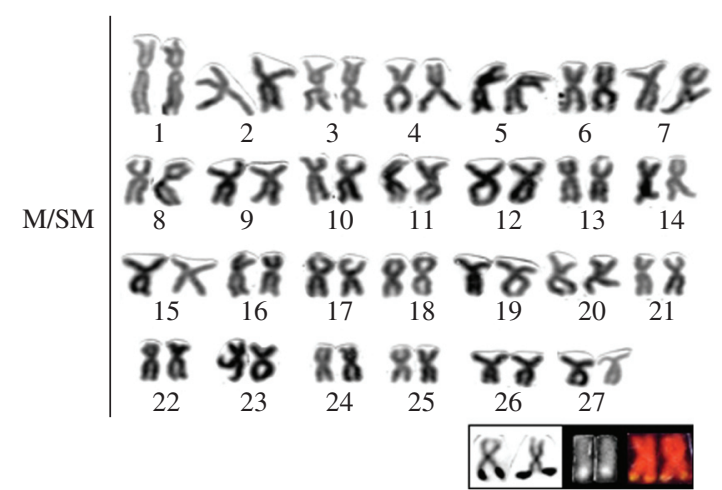

Figure 1. Giemsa-stained karyotype of Steindachnerina insculpta. The NOR-bearing chromosome pair 7 is shown in the box by silver nitrate (left), chromomycyn (middle), and 18S rDNA-FISH (right).

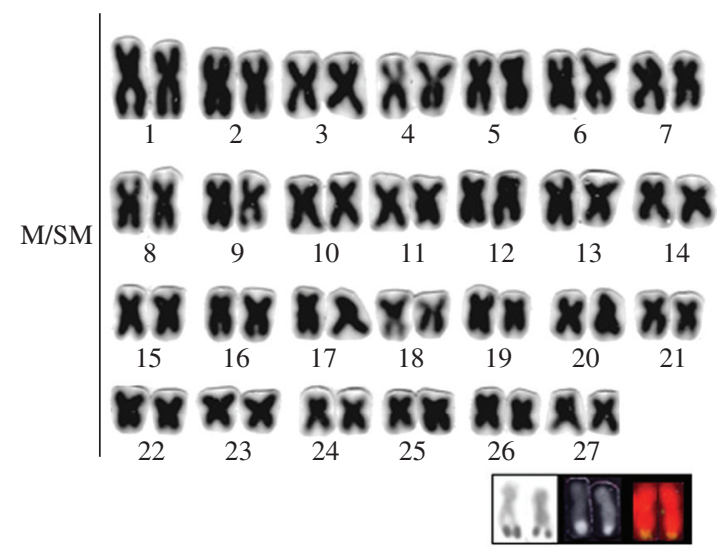

Figure 2. Giemsa-stained karyotype of Cyphocharax modesta. The NOR-bearing chromosome pair 2 is shown in the box by silver nitrate (left), chromomycyn (middle), and 18S rDNA-FISH (right).

Table 1). This same location was found in the specimens from the Paranapanema and Tietê Rivers.

Chromomycyn staining and in situ hybridization with a $18 \mathrm{~S}$ rDNA probe permitted the identification of a single large metacentric chromosome pair of $S$. insculpta and $C$. modesta, with bright signals on the terminal region of the long arm (Figures 1 and 2). No additional minor fluorescent signals were seen and one or two nucleoli were observed in the interphase nuclei cells. Figures 1 and 2 also show the chromosomes of $S$. insculpta and C. modesta that bear the $18 \mathrm{~S}$ rDNA cistrons.

Heterochromatin was seen through several centromeric and a few telomeric regions in the chromosomes of both species (Figure 3). Conspicuous heterochromatic blocks could be easily visualized on the long arm of the chromosome pair 2 of $C$. modesta and the chromosome
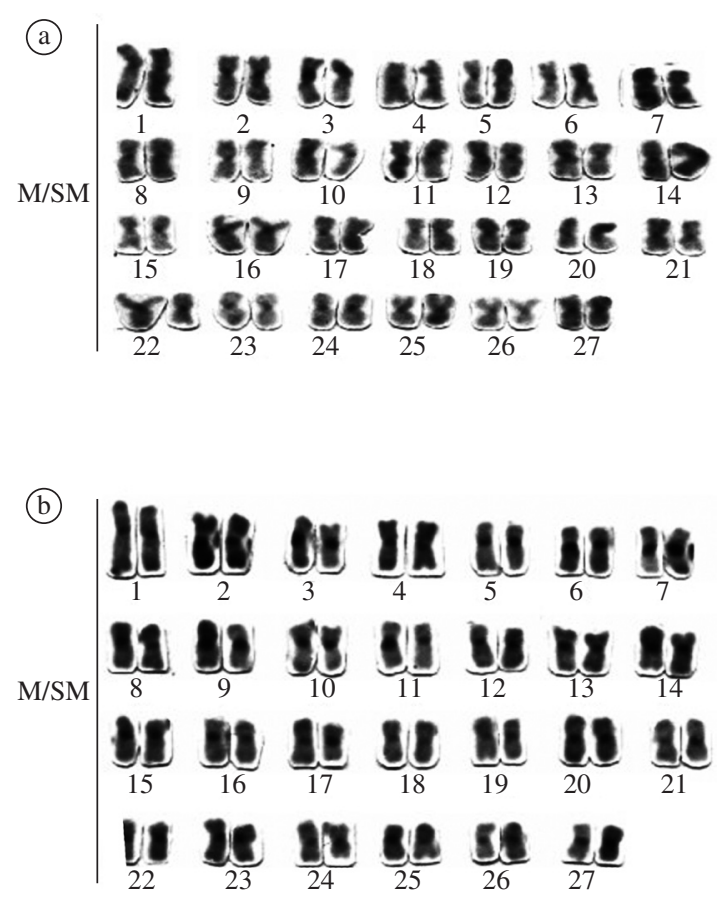

Figure 3. Constitutive heterochromatin patterns of a) Steindachnerina insculpta; and b) Cyphocharax modestus.

pair 7 of S. insculpta (Figure 3). No differences in the C-banding pattern were detected between the two samples of each species.

\section{Discussion}

The karyotypes of Steindachnerina insculpta and Cyphocharax modestus from the Paranapanema and Tietê Rivers, comprising 2n = 54 meta and submetacentric chromosomes, a single NOR bearing chromosome pair and heterochromatic segments in the centromeric region of almost all chromosomes, are closely similar to those found in most species of Curimatidae so far studied (Venere and Galetti, 1989; Feldberg et al., 1992; Oliveira and Foresti, 1993; Navarrete and Julio, 1997). The present results are congruent with previous data that indicate a high chromosome stability in Curimatidae and reinforces the idea that this fish group retains the diploid number of $2 n=54$ and a gross chromosome structure of a probable ancestral karyotype.

On the other hand, even though the karyotype macrostructure is practically invariable among the curimatids and the presence of a single NOR system is constantly observed in their complement, the NORs can be located on different chromosomes, representing species-specific cytogenetic markers. This fact was clearly evidenced in the present analyzed species - Ag-staining showed that even though Steindachnerina insculpta and Cyphocharax modestus present a single NOR pair, each species has specific NOR-bearing chromosomes. 
Table 1. NOR chromosome characterization in Steindachnerina insculpta and Cyphocharax modestus from different regions.

\begin{tabular}{|c|c|c|c|}
\hline Species & $\begin{array}{c}\text { NOR chromosome } \\
\text { location }\end{array}$ & $\begin{array}{c}\text { Chromosome } \\
\text { pair }\end{array}$ & Reference \\
\hline $\begin{array}{l}\text { Steindachnerina insculpta } \\
\text { (Paranapanema River - border municipality of } \\
\text { Paranapanema and Angatuba, São Paulo State, Brazil) }\end{array}$ & $\begin{array}{l}\text { long arm } \\
\text { large metacentric }\end{array}$ & 7 & Present paper \\
\hline $\begin{array}{l}\text { Steindachnerina insculpta } \\
\text { (Tietê River - municipality of Botucatu, São Paulo } \\
\text { State, Brazil) }\end{array}$ & $\begin{array}{l}\text { long arm } \\
\text { large metacentric }\end{array}$ & 7 & Present paper \\
\hline $\begin{array}{l}\text { Steindachnerina insculpta } \\
\text { (Mogi-Guaçu River - municipality of Pirassununga, } \\
\text { São Paulo State, Brazil) }\end{array}$ & $\begin{array}{l}\text { short arm } \\
\text { small metacentric }\end{array}$ & 25 & $\begin{array}{l}\text { Venere and Galetti } \\
\text { (1989) }\end{array}$ \\
\hline $\begin{array}{l}\text { Steindachnerina insculpta } \\
\text { (Tibagi River - municipality of Londrina, Paraná } \\
\text { State, Brazil) }\end{array}$ & $\begin{array}{l}\text { long arm } \\
\text { large metacentric }\end{array}$ & 7 & $\begin{array}{l}\text { Rodrigo Teribele } \\
\text { (personal } \\
\text { communication) }\end{array}$ \\
\hline $\begin{array}{l}\text { Steindachnerina insculpta } \\
\text { (Tibagi River - municipality of Londrina, Paraná } \\
\text { State, Brazil) }\end{array}$ & $\begin{array}{l}\text { long arm } \\
\text { large metacentric }\end{array}$ & 12 & $\begin{array}{l}\text { Waleska Gravena } \\
\text { (personal } \\
\text { communication) }\end{array}$ \\
\hline $\begin{array}{l}\text { Cyphocharax modestus } \\
\text { (Paranapanema River - border municipality of } \\
\text { Paranapanema and Angatuba, São Paulo State, Brazil) }\end{array}$ & $\begin{array}{l}\text { long arm } \\
\text { large metacentric }\end{array}$ & 2 & Present paper \\
\hline $\begin{array}{l}\text { Cyphocharax modestus } \\
\text { (Tietê River - municipality of Botucatu, São Paulo } \\
\text { State, Brazil) }\end{array}$ & $\begin{array}{l}\text { long arm } \\
\text { large metacentric }\end{array}$ & 2 & Present paper \\
\hline $\begin{array}{l}\text { Cyphocharax modestus } \\
\text { (Infernão Lagoon - Mogi-Guaçu River- municipality } \\
\text { of Luiz Antonio, São Paulo State, Brazil, and tribu- } \\
\text { tary of the Piracicaba River- municipality of Águas de } \\
\text { São Pedro, São Paulo State, Brazil }\end{array}$ & $\begin{array}{l}\text { long arm } \\
\text { large metacentric }\end{array}$ & 2 & $\begin{array}{l}\text { Venere and Galetti } \\
\text { (1989) }\end{array}$ \\
\hline $\begin{array}{l}\text { Cyphocharax modestus } \\
\text { (Tibagi River, municipality of Londrina, Paraná State, } \\
\text { Brazil) }\end{array}$ & $\begin{array}{l}\text { long arm } \\
\text { large metacentric }\end{array}$ & 2 & Martins et al. (1996) \\
\hline $\begin{array}{l}\text { Cyphocharax modestus } \\
\text { (Três Bocas Stream, municipality of Londrina, Paraná } \\
\text { State, Brazil) }\end{array}$ & $\begin{array}{l}\text { long arm } \\
\text { large metacentric }\end{array}$ & 2 & $\begin{array}{l}\text { Rodrigo Teribele } \\
\text { (personal communi- } \\
\text { cation) }\end{array}$ \\
\hline $\begin{array}{l}\text { Cyphocharax modestus } \\
\text { (Três Bocas Stream, municipality of Londrina, Paraná } \\
\text { State, Brazil) }\end{array}$ & $\begin{array}{l}\text { long arm } \\
\text { large metacentric }\end{array}$ & 2 & $\begin{array}{l}\text { Waleska Gravena } \\
\text { (personal communi- } \\
\text { cation) }\end{array}$ \\
\hline
\end{tabular}

Ag-NOR location in C. modesta is similar to that found for the same species from different Brazilian regions. Although some discrepancies could be observed between the NORs of S. insculpta from distinct rivers, most data seem to support the NOR location in a large submetacentric chromosome pair. Table 1 summarizes the NOR data for C. modesta and $S$. insculpta from different Brazilian freshwater systems and reinforces the proposition that these nucleolar cistrons can be used as species-specific cytogenetic markers. The distinct NOR location within the Curimatidae species could be due to internal chromosome modifications, such as translocations and/or inversions (Venere and Galetti, 1989).

The Ag-NORs localization was confirmed by chromomycyn-staining on mitotic chromosomes of S. insculpta and C. modesta. Although Ag-staining de- tects only transcriptional active NORs in the preceding interphase (Hsu et al., 1975), GC-specific fluorochromes such as $\mathrm{CMA}_{3}$ may reveal both active and inactive NORs in fish and amphibians (Mayr et al., 1986; Schmid and Guttenbach, 1988; Phillips and Hartley, 1988; Galetti and Rasch, 1993; Mestriner et al., 1995), probably as a consequence of the higher GC content of the rDNA (Schmid and Guttenbach, 1988). The NOR chromosome sites of $S$. insculpta and C. modesta have also been identified by fluorescent in situ hybridization using a $18 \mathrm{~S}$ rDNA probe, confirming the existence of a single locus for this gene family in both analyzed species from the Paranapanema and Tietê Rivers.

Despite the karyotype homogeneity observed in Curimatidae, variation on the amount and distribution of constitutive heterochromatin can be detected among 
some species. S. insculpta presented few heterochromatic blocks, as observed in the long arm of the NORbearing chromosome pair 7, according to previous data on this species (Venere, 1991). On the other hand, highly stained C-bands were evidenced in C. modesta, specially in the terminal region of the long arm of the NOR-bearing chromosome pair 2. The agreement of $\mathrm{C}$-bands and NOR sites is a common feature among fish species since the $45 \mathrm{~S}$ rDNA appears to be interspersed or adjacent to heterochromatin segments in these animals (Pendás et al., 1993; Galetti et al., 1994). The occurrence of constitutive heterochromatin blocks adjacent to nucleolar organizer regions may have facilitated chromosome breaks, thus permitting structural rearrangements concerning these regions (Moreira-Filho et al., 1984). Conspicuous heterochromatin blocks were also visualized on the second pair of Cyphocharax gilberti, C. nagelli, and Cyphocharax sp., suggesting that this could be a basal element in Curimatidae (Venere, 1991).

Although most Curimatidae species have been characterized by nearly homogeneous karyotypes, they can be found in quite diverse ecosystems in the Neotropical region (Vari, 1988). Consequently, isolated populations could be established under different environmental conditions leading to karyotypic microstructural variations, such as NOR localization and C-band distribution.

The present results were useful in the cytogenetic characterization and differentiation of Steindachnerina insculpta and Cyphocharax modestus and can also be used in evolutionary inferences in the Curimatidae fish group.

Acknowledgments - The authors thank Renato Devidé for helpful assistance. L.V.R.S. was supported by a fellowship from the Coordenação de Aperfeiçoamento de Pessoal de Nível Superior (CAPES). This work was also supported by grants from Conselho Nacional de Desenvolvimento Científico e Tecnológico $(\mathrm{CNPq})$ and Fundação de Amparo à Pesquisa do Estado de São Paulo (FAPESP).

\section{References}

AREFJEV, VA., 1990. Karyotypic diversity of characid families (Pisces, Characidae). Caryologia, vol. 43, p. 291-304.

BERTOLLO, LAC., MOREIRA-FILHO, O. and GALETTI, PM., 1986. Cytogenetics and taxonomy: considerations based on chromosome studies of freshwater fish. J. Fish Biol., vol. 28 , no. 2, p. 153-160.

BRASSESCO, MS., PASTORI, MC., RONCATI, HA. and FENOCCHIO, AS., 2004. Comparative cytogenetic studies of Curimatidae (Pisces, Characiformes) from the middle Paraná River (Argentina). Gen. Mol. Res., vol. 3, no. 2, p. 293-301.

BRUM, MJI. and GALETTI, PM., 1997. Teleostei ground plan karyotype. J. Comp. Biol., vol. 2, no. 2, p. 91-102.

CESTARI, MM., FERREIRA, R. and GALETTI, PM., 1990. Complemento cariotípico de duas espécies de peixes ornamentais: Chilodus punctatus (Chilodontidae) e Anostomus anostomus (Anostomidae) (Characiformes). In III Simpósio de Citogenética Evolutiva e Aplicada de Peixes Neotropicais. Resumos... Botucatu, SP, p. 3.

SANTOS, LVR., FORESTI, F., MARTINS, C., OLIVEIRA, C. and WASKO, AP., in press, Identification and description of distinct B chromosomes in Cyphocharax modestus (Characiformes, Curimatidae). Genetics and Molecular Biology.

FELDBERG, E., 1990. Estudos citogenéticos em 12 espécies de peixes da família Curimatidae (Characiformes) da Amazônia Central. (Tese de Doutorado) - Programa de Pós-graduação em Biologia de Água Doce e Pesca Interior. INPA. Manaus, AM, Brazil, p. 126.

FELDBERG, E., BERTOLLO, LAC., ALMEIDA-TOLEDO, LF., FORESTI, F., MOREIRA-FILHO, O. and SANTOS, AF., 1987. Biological aspects of Amazonian fishes. IX. Cytogenetic studies in two species of the genus Semaprochilodus (Pisces, Prochilodontidae). Genome, vol. 29, no. 1, p. 1-4.

FELDBERG, E., PORTO, JIR. and BERTOLLO, LAC., 1992. Karyotype evolution in Curimatidae (Teleostei, Characiformes) of the Amazon region. 1. Studies on the genera Curimata, Psectrogaster, Steindachnerina and Curimatella. Rev. Brasil. Genet., vol. 15, no. 2, p. 369-383.

FELDBERG, E., PORTO, JIR., NAKAYAMA, CM. and BERTOLLO, LAC., 1993. Karyotype evolution in Curimatidae (Teleostei, Characiformes) from the Amazon region. 2. Centric fissions in the genus Potamorhina. Genome, vol. 36, no. 2, p. 372-376.

FORESTI, F., OLIVEIRA, C. and ALMEIDA-TOLEDO, LF., 1993. A method for chromosome preparations from large specimens of fishes using in vitro short treatment with colchicine. Experientia, vol. 49, no. 9, p. 810-813.

GALETTI, PM., FORESTI, F., BERTOLLO, LAC. and MOREIRA-FILHO, O., 1981. Karyotypic similarity in three genera (Leporinus, Leporellus and Schizodon) of the family Anostomidae (Pisces, Teleostei). Rev. Brasil. Genet., vol. 4, p. 11-15.

GALETTI, PM., CESAR, ACG. and VENERE, PC., 1991. Heterochromatin and NORs variability in Leporinus fish (Anostomidae, Characiformes). Caryologia, vol. 44, p. 287-292.

GALETTI, PM. and RASCH, EM., 1993. Chromosome studies in Poecilia latipunctata with NORs polymorphism as shown by silver nitrate and chromomycin $\mathrm{A}_{3}$ (Teleostei: Poeciliidae). Ichthyol. Explor. Fresh., vol. 4, no. 3, p. 269-277.

GALETTI, PM., BERTOLLO, LAC. and MOREIRA-FILHO, O., 1994. Trends in chromosome evolution of neotropical characiform fishes. Caryologia, vol. 47, no. 3-4, p. 289-298.

GALETTI, PM., 1998. Chromosome diversity in neotropical fishes: NOR studies. Italian J. Zool., vol. 65, no. 53-56: Suppl. S, p. 53-56.

HAMKALO, BA. and ELGIN, SCR., 1991. Functional Organization of the Nucleolus: a Laboratory Guide. In: Hamkalo, BA. and SCR. Elgin (eds.), Methods Cell Biol., p. 670.

HOWELL, WM. and BLACK, DA., 1980. Controlled silverstaining of nucleolus organizer regions with a protective colloidal developer: a 1-step method. Experientia, vol. 36, no. 8 p. 1014-1015. 
HSU, TC., SPIRITO, SE. and PARDUE, ML., 1975. Distribution of $18 \mathrm{~S}+28 \mathrm{~S}$ ribosomal genes in mammalian genomes. Chromosoma, vol. 53, no. 1, p. 25-33.

MARTINS, C. and GALETTI, PM., 1999. Chromosomal localization of 5S rDNA genes in Leporinus fish (Anostomidae, Characiformes). Chrom. Res., vol. 7, no. 5, p. 363-367.

MARTINS C., GIULIANO-CAETANO, L. and DIAS AL., 1996. Occurrence of a B chromosome in Cyphocharax modestus (Pisces, Curimatidae). Cytobios, vol. 85, p.247-253

MAYR, B., RAB, P. and KALAT, M., 1986. NORs and counterstain-enhanced fluorescence studies in Cyprinidae of different ploidy level. Genetica, vol. 69, no. 2, p. 11-118.

MESTRINER, CA., BERTOLLO, LAC. and GALETTI, PM., 1995. Chromosome banding and synaptonemal complexes in Leporinus lacustris (Pisces, Anostomidae): analysis of a sex system. Chrom. Res., vol. 3, no. 7, p. 440-443.

MOREIRA-FILHO, O., BERTOLLO, LAC. and GALETTI, PM., 1984. Structure and variability of nucleolar organizer regions in Parodontidae fish. Can. J. Genet. Cytol, vol. 5, no. 26, p. 564-568.

NAVARRETE, MC., 1996. Estudos citogenéticos sobre curimatídeos do Pantanal do Mato Grosso do Sul (Osteichthyes: Characiformes: Curimatidae). (Tese de Mestrado) - Universidade Estadual de Maringá, PR, Brazil.

NAVARRETE, MC. and JÚLIO, HF., 1997. Cytogenetic analysis of four Curimatidae from the Paraguay basin, Brazil (Pisces: Characiformes: Curimatidae). Cytologia, vol. 62, p. 241-247.

OLIVEIRA, C. and FORESTI, F., 1993. Occurrence of supernumerary microchromosomes in Steindachnerina insculpta (Pisces, Characiformes, Curimatidae). Cytobios, vol. 76, p. 183-186.

OLIVEIRA, C., ALMEIDA-TOLEDO, LF., FORESTI, F., BRITSKI, HA. and TOLEDO-FILHO, SA., 1988. Chromosome formulae of Neotropical freshwater fishes. Rev. Brasil. Genet., vol. 11 , no. 3, p. 577- 624 .

PAULS, E. and BERTOLLO, LAC., 1990. Distribution of a supernumerary chromosome system and aspects of karyotypic evolution in the genus Prochilodus (Pisces, Prochilodontidae). Genetica, vol. 81, no. 2, p. 117-123.

PENDÁS, AM., MORÁN, P. and GARCIA-VÁZQUEZ, E., 1993. Multichromosomal location of ribosomal RNA genes and heterochromatin association in brown trout. Chrom. Res., vol. 1, no. 1, p. 63-67.

PHILLIPS, RB. and HARTLEY, SE., 1988. Fluorescent banding patterns of the chromosomes of the genus Salmo. Genome, vol. 30, no. 2, p. 193-197.
PINKEL, D., STRAUME, T. and GRAY, JW., 1986. Cytogenetic analysis using quantitative, high-sensitivity, fluorescence hybridization. Proc. Nat. Acad. Sci. USA, vol. 83, no. 9, p. 2934-2938.

SCHEEL, JJ., 1973. Fish chromosomes and their evolution. Internal Report of Danmartes Akvarvum. Charlotherlund, Denmark, p. 22.

SCHMID, M. and GUTTENBACH, M., 1988. Evolutionary diversity of reverse (R) fluorescent chromosome bands in vertebrates. Chromosoma, vol. 97, no. 2, p. 101-114.

SCHWEISER, D., 1976. Reverse fluorescent chromosome banding with Chromomycin and DAPI. Chromosoma, vol. 92, p. $143-148$.

SUMNER, AT., 1972. A simple technique for demonstrating centromeric heterochromatin. Exp. Cell Res., vol. 75, no. 1, p. 304-306.

VARI, RP., 1983. Phylogenetic relationships of the families Curimatidae, Prochilodontidae, Anostomidae and Chilodontidae (Pisces, Characiformes). Smiths. Contrib. Zool., vol. 378, p. 159.

VARI, RP., 1987. The Curimatidae a lowland Neotropical fish family (Pisces, Characiformes): distribution, endemism and phylogenetic biogeography, pp. 343-377, In: HEYER, WR. and VANZOLINI, PE. (eds.), Neotropical Distribution Patterns. Academia Brasileira de Ciências, Rio de Janeiro, Brasil.

VARI, RP., 1989. A phylogenetic study of the neotropical characiform family Curimatidae (Pisces, Ostariophysi). Smiths. Contrib. Zool., vol. 471, no. 4, p. 1-71.

VARI, RP., CASTRO, RMC. and RAREDON, SJ., 1995. The neotropical fish family Chilodontidae(Teleostei: Characiformes): a phylogenetic study and a revision of Centropus Günther. Smiths. Contrib. Zool., vol. 577, no. 32, p. 1-32.

VENERE, PC. and GALETTI, PM., 1989. Chromosome evolution and phylogenetic relationships of some Neotropical Characiformes of the family Curimatidae. Rev. Brasil. Genet., vol. 12, no. 1, p. 17-25.

VENERE, PC., 1991. Citogenética comparativa de peixes da família Curimatidae (Characiformes). Master Thesis. Universidade Federal de São Carlos, São Carlos, SP, Brazil.

WASKO, AP. and GALETTI, PM., 2000. Mapping 18S ribosomal genes in fish of the genus Brycon (Characidae) by fluorescence in situ hybridization (FISH). Genet. Mol. Biol., vol. 23, no. 1 p. 135-138.

WEITZMAN, SH. andVARI, RP., 1998. Characins and theirallies, In: JR. Paxton and WN. Eschmeyer (eds.), Encyclopedia of fishes. 2nd ed., Academic Press, San Diego, USA, p. 101-107 